\title{
SPOR LİGLERINNDE
}

\section{TÜKETICI ODAKLI MARKA}

\section{ÇAĞRIŞIMLARI}

\author{
Hacettepe Üniversitesi \\ iktisadi ve Idari Bilimler \\ Fakültesi Dergisi \\ Cilt 38, Sayı 2, 2020 \\ s. $373-386$
}

\author{
Kadir YAĞIZ \\ Dr., Hacettepe Üniversitesi \\ Sağlık Bilimleri Enstitüsü \\ kadiryagiz@hacettepe.edu.tr
}

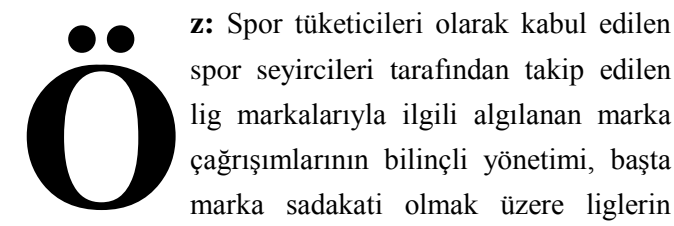

marka sermayesine önemli katkılar sağlamaktadır. Bu

güne kadar Türkiye'de spor liglerinin marka çağrışımlarına yönelik bir çalışma yapılmamıştır. Dolayısıyla, bu çalışmanın amacı spor lig marka çağrışımlarını incelemek ve lig marka çağrışımlarını futbol ve basketbol lig izleyicilerine göre farklı olup olmadığını test etmektir. Çalışmaya 176 futbol ligi izleyicisi, 184 basketbol ligi izleyicisi olmak üzere toplam 360 lig izleyicisi gönüllü olarak katılmıştır. Lig marka çağrışımlarını ölçmek için, literatürden uyarlanan marka çağrışım boyutları kullanılmıştır. Tek örneklem ttesti sonucuna göre kaçış, logo, stadyum atmosferi, nostalji, rekabet, gelenek, ürün sunumu, rekabetçi denge, sosyalleşme, yıldız oyuncu, oyunun temsili, özel takım ilgisi ve eğitim lig izleyicileri için önemli olabilecek çağrışımlar olarak bulunmuştur. Bağımsız örneklemler t-testi sonucuna göre, futbol ligi izleyicilerinin rekabetçi denge, oyunun temsili, özel takım ilgisi, rekabet, gelenek, lig özdeşleşmesi, yıldız oyuncu çağrışımlarını değerlendirme düzeyleri, basketbol ligi izleyicilerinin değerlendirme düzeylerinden daha büyük bulunurken; futbol ligi izleyicilerinin lig yönetimi çağrışımını değerlendirme düzeyleri, basketbol ligi izleyicilerinin değerlendirme düzeylerinden daha düşük bulunmuştur.

Anahtar Sözcükler: Marka çă̆rışımları, marka imajı, spor ligleri, spor lig izleyicileri. 
CONSUMER-BASED

\section{BRAND ASSOCIATIONS OF SPORTS LEAGUES}

\section{Kadir YAĞIZ}

Dr., Hacettepe University

Graduate School of Health Sciences

kadiryagiz@ hacettepe.edu.tr

\author{
Hacettepe University \\ Journal of Economics and \\ Administrative \\ Sciences \\ Vol. 38, Issue 2, 2020 \\ pp. 373-386
}

bstract: The conscious management of the
brand associations perceived related to the
league brands that are followed by sports
spectators which are considered as sports consumers, provides significant contributions to the brand equity of leagues, especially brand loyalty. Until now, there has been no study on the brand associations of sports leagues in Turkey. So, the aim of this study is to examine the sports league brand associations and testing whether the levels of evaluation of league brand associations differ according to soccer and basketball viewers. A total of 360 league viewers, 176 football league viewers and 184 basketball league viewers, participated in the study voluntarily. To measure the sports league brand associations, the brand associations dimensions adapted from the literature are used. According to the results of one sample t-test, the escape, logo, stadium atmosphere, nostalgia, rivalry, tradition, product delivery, competitive balance, socialisation, star player, game representation, special team interest and education are found to be important associations for sports league viewers. According to the results of independent samples t-test, the evaluation levels of football league viewers for the associations of competitive balance, game representation, special team interest, rivalry, tradition, league identification, star player are found to be higher than the evaluation levels of basketball league viewers. However, the evaluation level of football league viewers for league management association is found to be lower than the evaluation level of basketball league viewers.

Keywords: Brand associations, brand image, sports leagues, sports league viewers. 



\section{GíRiş}

Tüketici odaklı marka sermayesinin geliştirilmesinde, önemli bir işleve sahip marka çağrışımları, modern spor pazarlaması yönetiminin güncel konulardandır. Araştırmalar, kurumların marka sermayesi oluşturabilmesinde, mevcut ve potansiyel tüketicilerinin zihinlerinde güçlü ve olumlu bir imaj yaratabilmelerinin önemine işaret etmektedir (Mullin vd., 2007; Keller, 1993). Bununla beraber, marka imajının, farklı nitelikteki çağrışımların tüketicinin hafizasında yer edinmesi ile oluşabileceği belirtilmektedir (Aaker, 1991; Biel, 1992; Faircloth vd., 2001; Keller, 1993; Yoo vd., 2000). Dolayısıyla, marka çağrışımları, genellikle, marka sermayesi modelleri içerisinde, öncü unsurlarından biri olarak tanımlanmıştır (Williams, 2010). Marka çağrışımları, bir ürün markasına dair bireyin hafızasındaki tüm bilgi ve düşüncelerini içermektedir (Keller, 2008). Bu bilgiler ve düşünceler ürünün herhangi bir özelliği, kişiye sağladığı faydası, hatta ürünü temsil eden ya da ürünle ilişkilendirilen bir birey bile olabilmektedir (Aaker, 1996). Tüketiciler, reklam ve kişisel deneyimleriyle, bir markanın kendilerine yansıyan bu tip çağrışımlarını algılayarak, hafızalarında markaya ilişkin bir imaj oluşturmaktadırlar ve bu imaj aracılığıyla markaya bir anlam vermektedirler (Ross vd., 2006). Dolayısıyla, marka sermayesinin tüketicilerin zihinlerinde yaratıldığı dikkate alındığında, marka sermayesini ölçebilmek için ilk önce, pazarın markaya ilişkin algısını (marka çağrışımları) anlamak ve bilmek gerekmektedir (Villarejo Ramos, Martin Velicia, 2007).

Marka çağrışımlarının, satın alma niyeti, marka sadakati, algılanan kalite, marka farklılaşması, olumlu tutum ve hislerin yaratılması, marka için fazladan ödeme yapmaya gönüllü olma gibi unsurlar üzerinde etkili olduğu araştırmacılar (Aaker, 1991; Beech, Chadwick, 2007; Cobb-Walgren vd.,1995; Farquhar, 1989; Keller, 1993) tarafindan ortaya koyulmuştur. Sporda, olumlu marka çağrışımları aracılığıyla, medya da daha fazla yer alma, daha fazla lisanslı ürün ve bilet satışı, sponsorluk gibi finansal destekler sağlanması, sadık tüketici tabanın oluşturulması ve marka genişlemesi gibi önemli neticelerin elde edilebileceği vurgulanmıştır (Beech, Chadwick, 2007; Gladden vd., 1998). Örneğin, Manchester United futbol takımı güçlü bir marka olmasından dolayı Asya da satış ürünleri mağazası açabilmektedir (Gladden, Funk, 2002). UEFA şampiyonlar ligi yeniden markalaşması sonucunda dünya genelinde en çok seyredilen liglerden biri olmuştur (Chadwick, Holt, 2008). Dolayısıyla, tüketicilerin markaya yönelik olumlu tutum ve davranışlarında ve bunun sonucunda marka sermayesinin geliştirilmesinde önemli bir rolü olan marka çağrışımlarının spor ligleri bağlamında incelenmesi önemli bir araştırma konusudur.

\section{LITERATÜR}

Literatürde sporda marka çağrışımlarının incelendiği ilk çalışmalardan biri Gladden ve Funk (2001'nin çalışmasıdır. Örneklemini Amerika Birleşik Devletlerinde 
bir spor magazinine üye olan, Amerikan futbolu, beysbol, basketbol, buz hokeyi takımlarının taraftarlarının oluşturduğu ve profesyonel sporlarda marka sadakatinin nasıl oluştuğunu anlamaya yönelik yapılmış çalışmada, marka çağrışımları ile marka sadakati arasında önemli ilişkiler oluğu tespit edilmiştir. "Başarı" gibi önemli bir çağrışımın, marka sadakatini uzun vadede etkilememiş olması, buna karşın eğlenceye yönelik algıları kapsayan ve pazarlamacıların kontrol edebilecekleri "ürün sunumu" çağrışımının sadakat üzerinde etkili bulunması çalışmanın önemli sonuçlarındandır. Gladden ve Funk (2002), önceki çalışmalarındaki gibi, Amerikan futbolu, beysbol, basketbol ve buz hokeyi taraftarlarının oluşturduğu başka bir çalışmada, marka çağrışımlarını, Keller (1993)'ın önerilerine dayanarak ikinci düzey boyutlar altında sınıflandırmışlardır. Takımın performansına etki eden "yıldız oyuncu" ve satın almaya etki eden "stadyum" gibi çağrışımlar nitelik; bir takımı tutma aracılığıyla elde edilebilen "fan özdeşleşmesi" gibi çağrışımlar fayda ve "duygusal tepkiler" ise tutum olarak belirlenmiştir. Tüketici odaklı marka sermayesinin ölçümüne yönelik bir modelin sunulduğu çalışmada, Ross vd., (2008), marka çağrışımlarının, marka sermayesinin önemli bir boyutu olduğunu ileri sürmüşlerdir. NBA'de yer alan bir basketbol takımının tam sezon bilet sahiplerinin katılımıyla yapılan çalışmada, "başarı" ve "takımın nitelikleri” marka çağrışımını güçlü bir şekilde açıklayan çağrışımlar olarak tespit edilmiştir. Gladden ve Funk (2002)'nin çalışmasının aksine, Ross $v d$., (2008)'nin çalışmasında "başarı" çağrışımının güçlü bir şekilde algılanması, marka çağıışımlarının değişik spor izleyicilerine göre farklı şekilde algılanabileceğini ya da çağrışımların spor türüne göre farklılaşabileceğini göstermektedir. Bu durum, marka ve ürün sınıflarına göre marka çağrışımlarının farklılaşacağını belirtmiş Low ve Lamb (2000)'in görüşünü destekler niteliktedir. Bauer $v d$. (2008), Gladden ve Funk (2002)'dan uyarladıkları marka çağrışımlarının yanı sıra, Alman futbol yapısına özgü belirlenen diğer marka çağrışımlarını, takımların fanatikleri üzerinde test etmişlerdir. Çalışmada, marka çağrışımlarının birbirleri üzerinde etkilerinin yanı sıra tutumlar üzerinde de etkileri olduğu açığa çıkartılmıştır. Kunkel vd. (2009, 2014), literatürde bulunan takım marka çağrışımlarının, lig marka çağıışımlarını açıklamada kullanılabileceğini göstermişler ve bu çağrışımların yanı sıra, lig izleyicilerinden elde edilen liglere özgü yeni marka çağrışımlarını da açığa çıkartmışlardır. Kunkel vd. (2014), lig marka çağrışımlarının, bazı tutum ve davranışlarla ilişkili olduklarını da göstermişlerdir. Az sayıda da olsa Türkiye'de, özellikle futbol takımlarının çağrışımları üzerine yapılmış çalışmalar vardır. Yıldız (2016) Fenerbahçe, Galatasaray ve Beşiktaş futbol takımlarının taraftarları üzerinde, literatürdeki takım marka çağrışımlarını incelemiştir ve çağrışımları özellikler ve faydalar olarak sınıflandırmışıı. Yıldız vd. (2012) bir diğer çalışmasında marka çağrışımlarının marka güveni ve marka tatmini gibi diğer yapılar üzerinde etkileri olduğunu göstermiştir.

Sporda marka çağrışımlarını konu alan çalışmaların çoğunluğu spor takımları üzerinedir. Oysaki spor kulüplerinin içinde yer aldıkları spor ligleri de, gerek farklı spor 
ligleri gerekse eğlenceye yönelik diğer performansların arasından daha fazla izleyici, sponsor ve medya desteği kazanma baskısı altındadırlar. Spor liglerinin yöneticileri, sporda markalaşmanın yarattığı firsatlardan faydalanabilmelidirler. Lig yöneticileri, başarılı bir pazarlama programı hazırlayabilmek için kendi liglerinin marka çağrışımlarının neler olduğunu, hangilerinin izleyicileri tarafından daha fazla önemsendiğini ve bu marka çağrışımlarının güçlendirilmesi için neler yapabileceklerini bilmeleri gerekmektedir. Türkiye'de spor liglerinin marka çağrışımlarına yönelik herhangi bir çalışma yapılmamıştır ve lig izleyicilerinin liglere ilişkin marka çağrışımları algılarına dair bir veri bulunmamaktadır. Bu çalışmada, literatürdeki takım marka çağrışımları ile lig marka çağrışımları, Türkiye de marka sermayesine sahip olduğu düşünülen Süper Futbol ve Süper Basketbol Ligi kapsamında incelenecektir. Dolayısıyla çalışmada, lig izleyicilerinin lig marka çağrışımlarını değerlendirmeleri ve her iki lig izleyicilerine göre lig marka çağrışımlarını değerlendirme düzeylerinin farklı olup olmadığının incelenmesi amaçlanmıştır. Bu doğrultuda çalışmanın hipotezi şu şekilde oluşturulmuştur:

$\mathrm{H}_{1}$ : Süper Futbol Ligi izleyicileri ile Süper Basketbol Ligi izleyicilerinin tüketici odaklı marka çağrışımlarını değerlendirme düzeyleri arasında anlamlı farklılıklar vardır.

\section{YÖNTEM}

\section{1. Örneklem ve Veri Toplama Aracı}

Çalışmanın örneklemini, Ankara ilindeki Süper Futbol ve Süper Basketbol Ligi izleyicileri arasından gönüllü katılanlar oluşmaktadır. Örnekleme yöntemi olarak olasılıklı olmayan yöntemlerden kolayda örnekleme yöntemi seçilmiştir. Anketler, arena ve stadyuma lig maçlarını izlemeye gelenlere, ev sahibi takımın seyircilerinin ve misafir takımın seyircilerinin giriş yaptığı ayrı kapılarda olmak üzere 6 ana giriş alanı önünde ve spor kafelerde 4 hafta süreyle uygulanmıştır. Spor tüketicileri ile yapılan pazarlama çalışmalarında kolayda örneklem yöntemi ve stadyum ya da arena girişlerinde anket aracılığılla veri elde edilmesi sıklıkla kullanılmaktadır (bkz. Foroughi $v d$., 2016; Jae Ko $v d$., 2011). Eksik ya da değişkenlik içermeyen anketler çıkarıldıktan sonra 360 anket formundan elde edilen verilerle çalışmanın analizleri yapılmışıtır. Katılımciların 176's1 (\%48.9; $\left.\mathrm{x}_{\mathrm{yas}}=31.96 \pm 9,33\right)$ Süper Futbol Ligi izleyicisi, 184'ü $\left(\% 51.1 ; \mathrm{x}_{\text {yas }}=34.72 \pm 9.13\right)$ Süper Basketbol Ligi izleyicisi ve 267'si (\%74.2) erkek, 93'ü (\%25.8) kadındır. Katılımcıların 115'i (\%31.9) evli, 245'i (\%68.1) bekârken, 1'i $(\% 0.03)$ ilkokul, 10’u (\%2.8) ortaokul, 159’u (\%44.2) lise, 170'i (\%47.2) üniversite, 20'si (\%5.6) yüksek lisans mezunudur.

Anket formunun ilk bölümü, katılımcıların demografik yapısını anlamaya yönelik sorulardan oluşturmaktadır. İkinci bölümde, katılımcıların marka çağrışımlarını değerlendirme düzeylerini ölçen sorular yer almaktadır. Lig marka çağrışımlarının 
ölçülebilmesi için önceki yazarlar (Kunkel vd., 2009, 2014; Gladden, Funk, 2001, 2002; Ross $v d$., 2008) tarafindan geçerli ve güvenilir bulunmuş ölçeklerden bir madde havuzu oluşturulmuştur. Madde havuzundaki ölçeklere, Brislin (1990)'in önerisine uygun olarak, Türkçe- İngilizce-Türkçe eşdeğerlik çalışması yapılmıştır. Türkçeye çevrilmiş ölçekler, pazarlama konusunda uzman akademisyen ve futbol ve basketbol hakkında bilgi sahibi 8 kişilik bir grup tarafından, Türk lig sistemi çerçevesinde değerlendirilmiş̧tir. Nihai olarak, her biri üç madde ile ölçülen 16 faktör ve toplamda 48 maddeli lig marka çağrışımları ölçeği hazırlanmıştır. Çalışmada incelenecek lig çağrışımları şunlardır: kaçış, logo, stadyum atmosferi, nostalji, rekabet, gelenek, lig yönetimi, akran grup kabulü, ürün sunumu, lig özdeşleşmesi, rekabetçi denge, sosyalleşme, yıldız oyuncu, oyunun temsili, belirli bir takım ilgisi ve eğitim. Lig marka çağrışımları ve soru maddeleri, Kunkel vd., (2009, 2014)'nin çalışmalarından, Gladden ve Funk (2001)'ın geliştirdiği “Takım Çağrışım Modelinden” (Team Association Model-TAM) ve Ross $v d$., (2008)'nin geliştirdiği "Tüketici Odaklı Marka Sermayesi Modelinden" (Spectator Based Brand Equity- SBBE) uyarlanmıştır. Sorular 7'li Likert şeklindeki sorulardan oluşmuştur (1=Kesinlikle katılmıyorum; 2=Kesinlikle kat1lyorum).

\subsection{Verilerin Toplanması ve Verilerin Analizi}

Anket formuna son şeklini vermeden önce, sorun içeren maddelerin tespit edilmesi ve gerekli görülen yerlerde düzeltmelerin yapılabilmesi için, 55 katılımcı ile bir ön test yapılmıştır. Ön test sonucunda, değişkenlerin güvenirliklerinin sağlanmış olması üzerine, esas çalışma için tekrar anket toplanmıştır. Katılımcılara, anketin hangi amaçla yapıldığı, isim belirtmelerine gerek olmadığı ve sorulan sorulara katılma derecelerini puanlamaları konusunda bilgi verilmiştir.

Analizin ilk aşamasında, ölçeklerin güvenirlik ve geçerlikleri Cronbach Alpha $(\alpha)$ katsayısı ve düzeltilmiş madde-bütün korelasyonu (corrected item-total correlation) ile test edilmiştir. İkinci aşamada, her bir marka çağrışımı için ortalama değer oluşturulmuştur ve marka çağrışımları arasındaki ilişkiler korelasyon katsayıları ile test edilmiştir. Lig izleyicilerinin, lig marka çağrışımlarını değerlendirme düzeylerini belirlemek için, tek örneklem t-testi yapılmıştır. Bunun için, futbol ve basketbol ligi izleyicilerinin birlikte yer aldığı örneklemde ve ayrı olarak futbol ve basketbol lig örnekleminde, her bir çağrışım için elde edilen ortalama değer yedili Likert ölçeğinin ortası olarak kabul edilen 4,0 değeri ile karşılaşıırılmıştır. Son olarak, lig marka çağrışımlarını değerlendirme düzeylerinin futbol ve basketbol ligi izleyicilerine göre farklı olup olmadığı bağımsız örneklemler t-testi ile analiz edilmiştir. Analizler SPSS 22 programı ile yapılmıştır. 


\section{BULGULAR}

Güvenirlik analizinde oyunun temsili, gelenek, akran grup kabulü ve lig özdeşleşmesi çağrışımlarının güvenirliğini düşüren, açıklayıcı katsayısı düşük $(<0.25)$ birer madde gözlemlenmiş ve çıkartılmışlardır. Bu işlemden sonra, kaçış, nostalji, rekabet, lig yönetimi, akran grup kabulü, ürün sunumu, lig özdeşleşmesi, rekabetçi denge, yıldız oyuncu, oyunun temsili, özel takım ilgisi, eğitim ve stadyum atmosferi, $\alpha$ için $\geq 0.70$ (Nunnaly, 1978) değerini karşılamıştır. Logo $(\alpha=0.66)$, gelenek $(\alpha=0.69)$ ve sosyalleşme $(\alpha=0.67)$ çağrışımları 0.70 kestirim noktasına yakın bir şekilde değer almışlar ve $\alpha$ için 0.60-0.79 aralığının oldukça güvenilir olduğu (Alpar, 2010; Kalaycı, 2010) değerlendirilmesi neticesinde çalışmada kullanılmalarına karar verilmiştir. Tablo $1^{\prime}$ de, $\alpha$ değerleri ve çağrışımlar arasındaki korelasyon değerleri birlikte verilmiştir. Her bir maddenin ait olduğu çağrışımı ölçme gücü düzeltilmiş madde-bütün korelasyonları ile incelenmiştir. 16 çağrışımı açıklayan 44 madde, ilgili oldukları değişkenle en düşük 0.45 ve en yüksek 0.71 aralığında korelasyon değerlerine sahiptir. Düzeltilmiş maddebütün korelasyon katsayısı, maddenin ayırt ediciliği ya da diğer anlatımla maddenin geçerliği hakkında bilgi vermektedir. Pozitif ve 0.25 değerinden büyük olması istenmektedir (Alpar, 2010). Ayrıca geçerlik için çağrışımlar arasındaki korelasyonlar da incelenmiştir. Tabachnick ve Fidell (2001)'e göre, korelasyonlar arasındaki katsayının 0.90'a eşit ya da fazla olması durumunda çoklu bağlantı söz konusu olmaktadır ve bu ayırt edici geçerliğin sağlanamadığına işaret etmektedir. Korelasyonlar incelendiğinde, çağrışımlar arasında 0.90 ya da üzerinde bir ilişki bulunmamaktadır (bakınız Tablo 1.).

Tablo 2.' de tek örneklem t-testine ve bağımsız örneklemler için t-testine ilişkin sonuçlar verilmiştir. Tek örneklem $t$ testi sonucuna göre, ortak örneklemde lig yönetimi $(\mathrm{x}=4.10)$ ve lig özdeşleşmesi $(\mathrm{x}=3.92)$ ortalamaları ile test değeri 4.0 arasında anlamlı bir fark bulunmazken $(p>0.05)$ diğer çağrışımlar test değeri 4.0 dan anlamlı bir şekilde farklıdır $(\mathrm{p}<0.05)$. Akran grup kabulü çağrışımının ortalaması $(x=3.19) 4.0$ test değerinin altında kalırken, kaçış, logo, nostalji, rekabet, gelenek, ürün sunumu, rekabetçi denge, sosyalleşme, yıldız oyuncu, oyunun temsili, özel takım ilgisi, eğitim ve stadyum atmosferi çağrışımlarının ortalamaları üzerindedir. Futbol örnekleminde, lig özdeşleşmesi ortalaması $(x=4.14)$ ile 4.0 test değeri arasında anlamlı bir fark bulunmazken $(\mathrm{p}>0.05)$, diğer ortalamalar test değerinden anlamlı bir şekilde farklıdır $(\mathrm{p}<0.05)$. Akran grup kabulü $(x=3.20)$ ve lig yönetimi $(x=3.59)$ çağrışımının ortalaması 4.0 test değerinin altında kalırken, uzaklaşma, logo, nostalji, rekabet, gelenek, ürün sunumu, rekabetçi denge, sosyalleşme, yıldız oyuncu, oyunun temsili, özel takım ilgisi, eğitim ve stadyum atmosferi çağrışımlarının ortalamaları üzerindedir. Basketbol örnekleminde, tüm ortalamalar 4,0 test değerinden anlamlı bir şekilde farklıdır $(\mathrm{p}<0.05)$. Akran grup kabulü $(\mathrm{x}=3.18)$ ve lig özdeşleşmesi $(\mathrm{x}=3.70)$ ortalaması 4.0 test değerinin altında kalırken, diğer tüm çağrışımların ortalamaları üzerindedir. 
YAĞIZ | Consumer-Based Brand Associations of Sports Leagues

Tablo 1. Lig Marka Çağrışımlarının Güvenirlikleri ( $\alpha$ ) ve Çağrışımlar Arasındaki Korelasyonlar

\begin{tabular}{|c|c|c|c|c|c|c|c|c|c|c|c|c|c|c|c|c|c|}
\hline \multirow[b]{2}{*}{ Çağrışımlar } & \multicolumn{17}{|c|}{ Futbol - Basketbol n= $\mathbf{3 6 0}$} \\
\hline & $\alpha$ & 1. & 2. & 3. & 4. & 5. & 6. & 7. & 8. & 9. & 10. & 11. & 12. & 13. & 14. & 15. & 16. \\
\hline 1. Kaçıs & 0.77 & & & & & & & & & & & & & & & & \\
\hline 2. Logo & 0.66 & 0.30 & & & & & & & & & & & & & & & \\
\hline 3. Stadyum Atmosferi & 0.71 & 0.31 & 0.48 & & & & & & & & & & & & & & \\
\hline 4. Nostalji & 0.71 & 0.44 & 0.38 & 0.38 & & & & & & & & & & & & & \\
\hline 5. Rekabet & 0.79 & 0.27 & 0.42 & 0.66 & 0.49 & & & & & & & & & & & & \\
\hline 6. Gelenek & 0,69 & 0.17 & 0.40 & 0.53 & 0.40 & 0.56 & & & & & & & & & & & \\
\hline 7. Lig Yönetim & 0.82 & 0.26 & 0.58 & 0.45 & 0.33 & 0.25 & 0.30 & & & & & & & & & & \\
\hline 8. Akran grup kabulü & 0.72 & 0.01 & 0.09 & 0.07 & 0.89 & -0.08 & 0.17 & 0.18 & & & & & & & & & \\
\hline 9. Ürün sunumu & 0.81 & 0.33 & 0.52 & 0.75 & 0.60 & 0.78 & 0.62 & 0.42 & 0.01 & & & & & & & & \\
\hline 10. Lig özdeşleşmesi & 0.71 & 0.31 & 0.33 & 0.47 & 0.49 & 0,30 & 0.36 & 0.25 & 0.30 & 0.45 & & & & & & & \\
\hline 11. Rekabetçi denge & 0.74 & 0.08 & 0.16 & 0.46 & 0.38 & 0.49 & 0.44 & 0.09 & 0.20 & 0.47 & 0.35 & & & & & & \\
\hline 12. Sosyalleşme & 0.67 & 0.26 & 0.29 & 0.42 & 0.54 & 0.30 & 0.31 & 0.25 & 0.41 & 0.39 & 0.49 & 0.43 & & & & & \\
\hline 13. Yildız oyuncu & 0.79 & 0.26 & 0.31 & 0.62 & 0.47 & 0.76 & 0.48 & 0.15 & -0.11 & 0.70 & 0.29 & 0.51 & 0.32 & & & & \\
\hline 14. Oyunun temsili & 0.74 & 0.30 & 0.22 & 0.53 & 0.50 & 0.62 & 0.40 & 0.06 & -0.09 & 0.61 & 0.32 & 0.47 & 0.33 & 0.69 & & & \\
\hline 15. Özel takım ilgisi & 0.79 & 0.31 & 0.31 & 0.61 & 0.54 & 0.74 & 0.45 & 0.13 & -0.10 & 0.70 & 0.36 & 0.49 & 0.31 & 0.78 & 0.71 & & \\
\hline 16. Eğitim & 0.83 & 0.36 & 0.39 & 0.65 & 0.55 & 0.62 & 0.42 & 0.34 & 0.04 & 0.69 & 0.36 & 0.42 & 0.39 & 0.59 & 0.57 & 0.59 & \\
\hline
\end{tabular}

Hacettepe University Journal of Economics and Administrative Sciences

Vol 38, Issue 2, 2020

380 
Tablo 2. Tek Örneklem t-testi ve Bağımsız Örneklemler t-testi Sonuçları

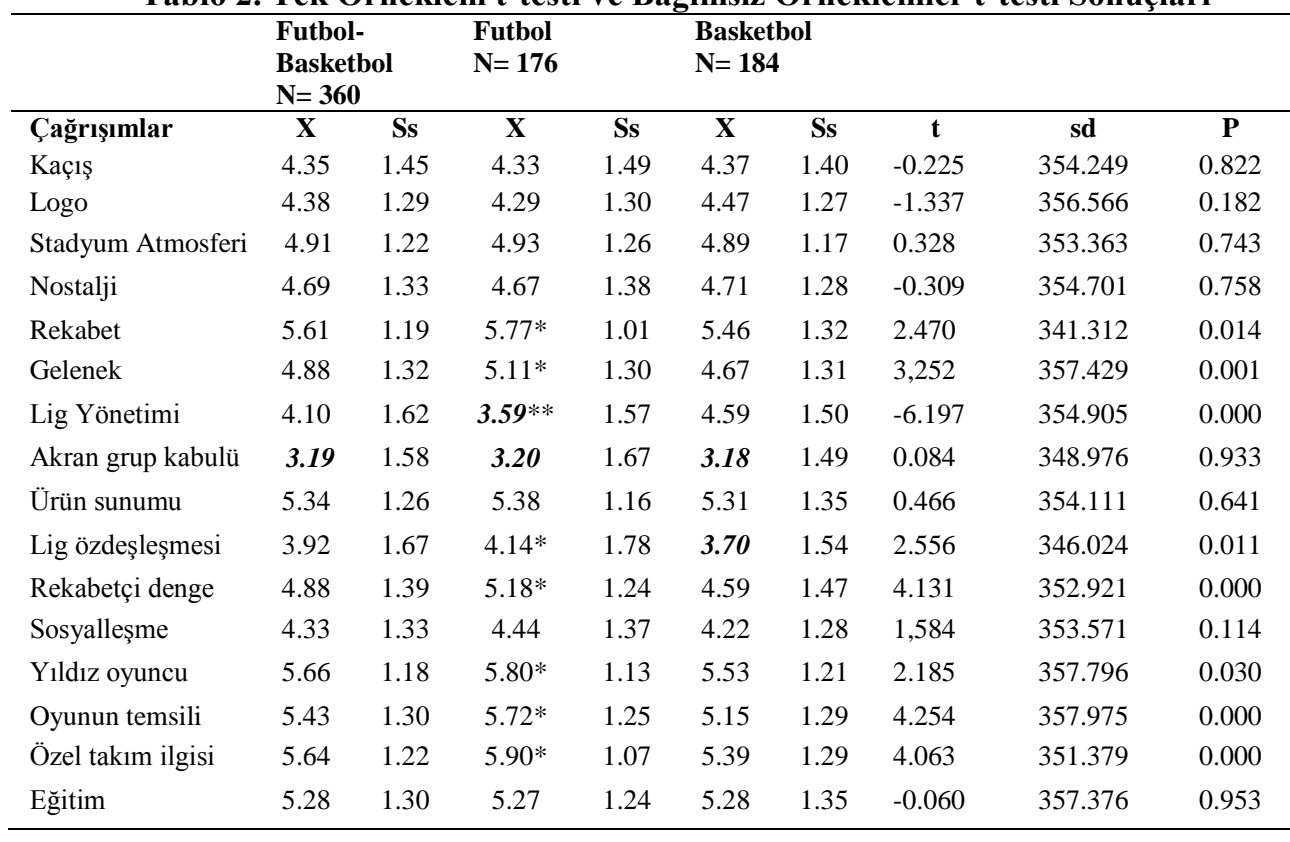

Koyu ve italik olanlar anlamlı bir şekilde test değeri 4.0'dan farklı ve düşük $(\mathrm{p}<0.05)$. *Basketbol ligine göre anlamlı bir şekilde farklı ve yüksek $(\mathrm{p}<0.05)$.

**Basketbol ligine göre anlamlı bir şekilde farklı ve düşük $(\mathrm{p}<0.05)$.

Çalışmada kullanılan verilerin çarpıklık ve basıklık değerleri normal dağılım varsayımı için gerekli $+/-1.5$ aralığında (Bayram, 2013) olsa da, t-testinin varsayımlarından bir diğeri olan varyansların homojen olup olmadı̆̆ını öğrenmek amacıyla yapılan test de (Levene's test for equality of variances) bazı çağrışımlar varyansların homojenliği varsayımını karşılayamamıştır. Buna rağmen, $\mathrm{p}$ değeri genelde tutarlı sonuçlar vermekteyse de, varyansların homojen olmadığı durumlar için test istatistiği, Welch $\mathrm{t}$ istatistiği adı verilen ve farklı bir hesaplama tekniğine dayalı alternatif bir çözüm sunmaktadır (Kent State University Libraries, 2018). Dolayısıyla, test sonuçları varyansların homojen olmadığını varsayan test istatistiklerine göre değerlendirilmiş̧ir. Test sonuçlarına göre, her iki lig izleyicilerinin, bazı marka çağrışımlarını değerlendirme düzeylerinin ortalaması arasında anlamlı farklılıklar bulunmuştur (bakınız Tablo 2). Buna göre, futbol ligi izleyicilerinin, rekabetçi denge, oyunun temsili, özel takım ilgisi, rekabet, gelenek, lig özdeşleşmesi, yıldız oyuncu, çağrışımlarını değerlendirmelerinin ortalaması, basketbol ligi izleyicilerinin ortalamasından anlamlı bir şekilde daha büyüktür $(\mathrm{p}<0.05)$. Buna karşın futbol ligi izleyicilerinin, lig yönetimi çağrışımını değerlendirmelerinin ortalaması, basketbol ligi izleyicilerinin ortalamasından anlamlı bir şekilde daha düşüktür $(\mathrm{p}<0.05)$. Kaçış, logo, stadyum atmosferi, nostalji, akran grup kabulü, sosyalleşme ve eğitim $(p>0.05)$ 
çağrışımlarının ortalaması bakımından her iki lig izleyicileri arasında bir fark bulunmamıştır.

\section{TARTISMA}

$\mathrm{Bu}$ çalışmanın amacı, spor lig marka çağrışımlarını incelemek ve lig marka çağrışımlarını değerlendirme düzeylerinin futbol ve basketbol izleyicilerine göre farklı olup olmadığını test etmektir. Çağrışımlar içinde akran grup kabulü, her iki ligin birlikte değerlendirildiği ortak örneklemin yanı sıra futbol ve basketbol örneklemlerinde de, lig izleyicileri tarafından en düşük düzeyde değerlendirilmiş ve 4.0 ortalama değerinin altında kalmıştır. Ortak örneklemde, lig özdeşleşmesi her ne kadar 4.0 ortalama değerinin hemen altında $(x=3.92)$ kalmış olsa da, test sonucu bu değerin 4.0 değerinden farklı olmadığını ortaya koymuştur. Dolayısıyla, ortak örneklem bakımından değerlendirildiğinde, lig özdeşleşmesi dahil olmak üzere, kaçış, logo, nostalji, rekabet, gelenek, ürün sunumu, lig yönetimi, rekabetçi denge, sosyalleşme, y1ldız oyuncu, oyunun temsili, özel takım ilgisi, eğitim ve stadyum atmosferi çağrışımları lig izleyicileri tarafindan yüksek düzeyde değerlendirilmiştir. Akran grup kabulünün yanı sıra 4.0 ortalama değerinin altında kalan çağrışımlar, futbol örnekleminde lig yönetimi iken, basketbol örnekleminde lig özdeşlemesi olmuştur. Dolayısıyla, futbol lig izleyicileri akran grup kabulü ve lig yönetimi dışında, basketbol lig izleyicileri ise akran grup kabulü ve lig özdeşleşmesi dışında kalan tüm çağrışımları yüksek düzeyde değerlendirmişlerdir. Bu çalışmada, akran grup kabulünün, lig izleyicileri tarafindan yüksek düzeyde değerlendirilmemesi önceki çalışmalardaki sonuçlarla (Kunkel vd., 2009, Gladden, Funk, 2002; Yıld1z, 2016) benzeşmektedir. Kunkel vd. (2009)'nin çalışmalarında da, lig özdeşlemesi çağrışımı Avustralya futbolu, rugby ve futbol ligi izleyicilerince yeterince yüksek düzeyde değerlendirilmemiştir. Dolayısıyla, bir spor ligini takip etme aracılığıyla, belirli bir sosyal çevre tarafından kabul görme anlayışına (akran grup kabulü) gerek futbol gerekse basketbol lig izleyicileri katılmamaktadır. Diğer yandan, lig yönetiminin lig başarısına olan katkısına ve ligin iyi yönetildiğine futbol lig izleyicileri katılmazken, lig aracılığıyla başarılı bir nesne ile ilişkilendirilmiş olma ve lig fanatiği olarak bundan gurur duyma anlayışına (lig özdeşleşmesi) basketbol lig izleyicileri katılmamaktadır.

Çalışmanın sonuçları, futbol ve basketbol ligi izleyicilerinin bazı lig marka çağrışımlarını değerlendirme düzeylerinin farklı olduğunu ortaya koymuştur. Futbol ligi izleyicilerinin, rekabetçi denge, oyunun temsili, özel takım ilgisi, rekabet, gelenek, lig özdeşleşmesi, yıldız oyuncu çağrışımlarını değerlendirme düzeyleri, basketbol ligi izleyicilerinin değerlendirme düzeylerinden daha büyüktür. Buna karşın futbol ligi izleyicilerinin, lig yönetimi çağrışımını değerlendirme düzeyleri, basketbol ligi izleyicilerinin değerlendirme düzeyinden daha düşüktür. Kaçış, logo, stadyum atmosferi, nostalji, akran grup kabulü, sosyalleşme ve eğitim çağrışımlarını değerlendirme düzeyleri bakımından her iki lig izleyicileri arasında bir fark yoktur. Bazı 
marka çağrışımlarının değerlendirilme düzeyinin futbol ve basketbol lig izleyicileri arasında farklılık göstermesi, izleyicilerin cinsiyet gibi diğer önemli demografik özelliklerin ve ilgilenim düzeylerinin hariç tutulması koşuluyla, öncelikle liglerin özellikleri ile ilişkilendirilebilir. Türkiye'de, futbol liginin, basketbol ligine göre daha popüler olması, özellikle medyada futbolun daha fazla yer alması sonucunda, Süper Futbol Liginde yer alan takımların ve oyuncuların nitelikleri, birçok spor izleyicisi tarafindan daha fazla bilinmektedir. Hatta futbol takımları ve yıldız oyuncuları Türkiye'de günlük yaşamın vazgeçilmez konularıdır. Diğer yandan, futbol ligini basketbol liginden ayıran belki de önemli özelliklerden biride, Türkiye'de futbol fanatiklerinin, basketbol fanatiklerine göre daha tutkulu olarak bilinmeleridir. Dolayısıyla, futbol lig izleyicilerinin özel takım ilgisi, yıldız oyuncu ve lig özdeşleşmesi gibi bazı çağrışımları değerlendirme düzeylerinin basketbol lig izleyicilerinin değerlendirme düzeylerinden daha yüksek olması, lig izleyicilerinin nitelikleri ve liglerin özel yapısı ile ilişkilendirilebilir. Diğer yandan, basketbol ligi izleyicilerinin lig yönetimi çağrışımını değerlendirmelerinin, futbol ligi izleyicilerine göre daha yüksek olmas1, 2010-2011 sezonunda Süper Futbol Liginde yaşanmış olan şike skandalıyla kısmen ilişkilendirilebilir. $\mathrm{Bu}$ skandalın ardından bazı yönetici ve sporcuların yargılanmaları uzun bir süre gündemi meşgul etmiştir ve halen bu çalışmanın yapılmış olduğu dönemde de etkisini göstermekte olabilir. Bununla beraber, lig izleyicilerinin hafızalarında bulunan lig ile ilgili mevcut marka çağrışımlarının, ligin geçmişi ya da önceki pazarlama çabaları sonucunda oluşmuş olduğu gerçeği göz önünde bulundurulmalıdır.

\section{SONUC}

$\mathrm{Bu}$ çalışmada, literatürdeki takım ve lig marka çağrışımlarının Türk spor liglerine uyarlanabileceği gösterilmiş, potansiyel marka çağrışımlarının neler olabileceği açığa çıkartılmış ve bazı lig marka çağrışımlarının değerlendirilme düzeyinin Süper Futbol ve Süper Basketbol Lig izleyicilerine göre farklılaştığı tespit edilmiştir. Genel olarak, Süper Futbol ve Basketbol Ligi izleyicilerinin "kaçış", "logo", "stadyum atmosferi", "nostalji", "rekabet", "gelenek", "ürün sunumu", "rekabetçi denge", "sosyalleşme", "yıldız oyuncu", "oyunun temsili", "özel takım ilgisi" ve "eğitim" çağrışımlarını değerlendirme düzeyleri yüksek bulunmuştur. Bu marka çağrışımları, spor lig yöneticilerine, lig izleyicilerinin hafızalarındaki markalarının konumuna dair bilgi vermektedir. Lig izleyicileri tarafindan yüksek düzeyde değerlendirilen çağrışımlar lig markalarının güçlü oldukları noktalara işaret etmekte ve marka imajına olumlu yönde katkı sağlamaktadırlar. Lig izleyicileri tarafından düşük düzeyde değerlendirilen çağrışımlar ise lig markalarının zayıf oldukları noktalara ve marka imajını olumsuz etkileyebilecek durumlara ilişkin bilgi vermektedir. Örneğin, Süper Futbol Lig izleyicileri bakımından en yüksek düzeyde değerlendirilen çağrışım özel takım ilgisidir. Buna göre, Süper Futbol Liginde yer alan takımların cazibesinin, bu ligin izleyicilerinin hafızalarındaki lige ilişkin imaja olumlu ve önemli ölçüde katkı 
sağladığı söylenebilir. Diğer yandan, lig yönetimi çağrışımı Süper Futbol Ligi izleyicileri tarafından en düşük düzeyde değerlendirilmiştir. Bu lig yönetimi ve lig izleyicileri arasında bir olumsuzluğun ya da güven eksikliğinin işaretçisi olabilir. Dolayısıyla, Süper Futbol Lig yöneticileri, özel takım ilgisi ile birlikte yıldız oyuncu ve rekabet gibi futbol lig izleyicileri tarafindan önemli düzeyde değerlendirilen çağrışımları, izleyicilerine yönelik iletişimlerinde muhafaza etmeli ve öne çıkarmalıdır. Ayrıca, en düşük düzeyde değerlendirilen lig yönetimi çağrışımının yanı sıra logo ve lig özdeşleşmesi gibi yeterli düzeyde ancak göreceli olarak daha düşük değerlendirilmiş çağrışımları geliştirme yönünde çaba sarf etmelidirler. Bunun için Süper Futbol Lig yöneticileri ve taraftarların birlikte yer alacakları, birbirleri ile daha fazla etkileşimde olacakları sosyal etkinlikler düzenlenebilir; lig logosu, şekli ve renkleri ile daha fazla farkındalık yaratacak şekilde tasarlanabilir. Diğer yandan, Süper Basketbol Lig yöneticileri ise, Basketbol lig izleyicileri tarafından en yüksek düzeyde değerlendirilen sırasıyla yıldız oyuncu, rekabet ve özel takım ilgisi çağrışımlarını, lige ilişkin imajın olumlu yönde artması için ön plana çıkartmalıdır. Bununla beraber, Basketbol lig izleyicileri tarafından en düşük düzeyde değerlendirilen lig özdeşleşmesi çağrışımın yanı sıra yine göreceli olarak düşük olan sosyalleşme ve uzaklaşma çağrışımlarını geliştirme yönünde çaba sarf etmeleri önerilebilir. Örneğin, Süper Basketbol Lig yöneticileri, izleyicileri açısından aidiyet duygusunu geliştirebilecek, lig taraftarlarına bazı avantajlar sağlayabilecek bankalarla anlaşmalı kredi kartı, indirim çekleri ya da lisanslı ürünleri çeşitlendirme yoluyla değişik tutundurma yöntemleri geliştirebilirler. Sonuç olarak, spor lig yöneticilerinin bu marka çağrışımlarını başarılı bir şekilde yönetmesi, sadık tüketici tabanının oluşturulmasına ve dolayısıyla ekonomik başarılarının devam etmesine imkân verecektir.

Örneklemin sadece Ankara'da bulunan lig izleyicilerinden oluşması çalışmanın önemli kısıtlarından biri olarak değerlendirilebilir. Ayrıca, çalışmada lig marka çağrışımlarını değerlendirme düzeylerinin değişik lig izleyicilerine göre farklılaşıp farklılaşmadığı incelenmiş olsa da, lig izleyicilerinin demografik yapılarına göre bir değerlendirme yapılmamıştır. Sonraki çalışmalarda, Türkiye genelini temsil edebilmesi açısından, çağrışımların farklı bölgelerdeki lig izleyicilerinin birlikte yer aldığı örneklemde değerlendirilmesi ve lig izleyicilerinin demografik özellikleri ya da lig tüketim biçimleri dikkate alınarak, değişik kategorilerdeki izleyicilere göre lig marka çağrışımları incelenebilir. Buna ilaveten, gelecekteki çalışmalarda, spor karşılaşmalarındaki performansların öngörülememesi ve sporun bir hizmet olması gibi nedenlere bağlı olarak, müşterilerin bir hizmeti öznel yargılamasını kapsayan müşteri tatmini ile marka çağrışımları ve marka sadakati arasındaki ilişkiler incelenebilir. Marka çağrışımları ile marka sadakati arasındaki ilişkide, özellikle, müşterilerin bir sportif etkinlikte deneyimlediği hizmetlerden genel tatminini kapsayan hizmet tatmini ve müşterilerin sahadaki spor karşılaşmasındaki oyuna iliş̧in genel tatmini kapsayan oyun 
tatmini gibi değişkenlerin aracılık ilişkilerinin test edilmesi, sporda markalaşma literatürüne katkı sağlayabilecek önemli bulguları açığa çıkartabilir.

\section{KAYNAKLAR}

Aaker, D.A. (1991), Managing Brand Equity: Capitilazing on the Value of a Brand Name, New York: Free Press.

Aaker D.A. (1996), Building Strong Brands, New York: Free Press.

Alpar R. (2010), Spor, Sağllk ve Eğitim Bilimlerinden Örneklerle Uygulamalı İstatistik ve Geçerlik-Güvenirlik, Ankara: Detay Yayıncıllk.

Bauer H.H, NE Stokburger-Sauer, S. Exler (2008), "Brand Image and Fan Loyalty in Professional Team Sport: A Refined Model and Empirical Assessment", Journal of Sport Management, 22(2), 205-226.

Bayram N. (2013), Yapısal Eşitlik Modellemesine Giriş̧ Amos Uygulamaları, Bursa: Ezgi Kitabevi.

Beech J.G., S. Chadwick (Eds.) (2007), The Marketing of Sport, England: Pearson Education

Biel AL. (1992), "How Brand Image Drives Brand Equity", Journal of Advertising Research, 32(6), 6-12.

Brislin RW. (1990), Applied Cross-Cultural Psychology, Newbury Park, CA: Sage Publication Inc.

Chadwick S, M. Holt (2008), "Releasing Latent Brand Equity: The Case of UEFA's Champions League", Marketing Review, 8(2), 147-162.

Cobb-Walgren CJ, CA Ruble, N. Donthu (1995), "Brand Equity, Brand Preference, and Purchase Intent", Journal of Advertising, 24(3), 25-40.

Faircloth J, L. Capella, B. Alford (2001), "The Effect of Brand Attitude and Brand Imageon Brand Equity", Journal of Marketing Theory and Practice, 9(3), 61-75.

Farquhar PH. (1989), "Managing Brand Equity", Marketing Research, 1 (3), 24-33

Foroughi, B., D. Nikbin, S.S., Hyun, M. Iranmanesh (2016), "Impact of Core Product Quality on Sport Fans' Emotions and Behavioral Intentions". International Journal of Sports Marketing and Sponsorship, 17(2), 110-129.

Gladden, JM, G.R. Milne, WA. Sutton (1998), "A Conceptual Framework for Assessing Brand Equity in Division I College Athletics", Journal of Sport Management, 12(1), 1-19.

Gladden JM, DC. Funk (2001), "Understanding Brand Loyalty in Professional sport: Examining the Link Between Brand Associations and Brand Loyalty", International Journal of Sports Marketing and Sponsorship, 3(1), 54-81.

Gladden J.M, D.C. Funk (2002), "Developing an Understanding of Brand associations in Team Sport: Empirical Evidence from Consumers of ProfessionalS", Journal of Sport Management, 16(1), 54-81.

Jae Ko, Y., J. Zhang, K. Cattani, D. Pastore (2011), "Assessment of Event Quality in Major Spectator Sports”, Managing Service Quality: An International Journal, 21(3), 304-322. 
Kalaycı Ş. (2010), SPSS Uygulamalı Çok Değişkenli İstatistik Teknikleri, Ankara: Asil Yayın Dağıtım Ltd. Şti.

Keller K.L. (1993), “Conceptualizing, Measuring, and Managing Customer-based Brand Equity”, The Journal of Marketing, 57(1), 1-22.

Keller K.L. (2008), Strategic Brand Management: Building, Measuring, and Managing Brand Equity, Upper Saddle River, NJ: Prentice Hall.

Kent State University Libraries (2018), SPSS Tutorials: Independent Samples $t$ Test, Son güncelleme 07.11.2018. https://libguides.library.kent.edu/SPSS/IndependentTTest (E.T.: 17.11.2018)

Kunkel T, D. Funk, C. King (2009), "In Sustainable Management and Marketing: Proceedings of Australia and New Zealand Marketing Academy Conference: Consumer Based Brand Associations for Professional Football Leagues. Melbourne, VIC.

Kunkel T, D. Funk, C. King (2014), "Developing a Conceptual Understanding of Consumerbased League Brand Associations", Journal of Sport Management, 28(1), 49-67

Low GS, C.W. Lamb (2000), "The Measurement and Dimensionality of Brand Associations", The Journal of Product and Brand Management, 9(6), 350-70.

Mullin B.J, S. Hardy, W.A. Sutton (2007), Sport Marketing (3.bs.). Champaign, IL: Human Kinetics.

Nunnally J.C. (1978), Psychometric Theory, 2nd. ed., New York: McGraw Hill.

Ross S.D., J.D. James, P. Vargas (2006), "Development of a Scale to Measure Professional Sport Team Brand Associations”, Journal of Sport Management, 20, 260-279.

Ross S.D., K.C. Russell, H. Bang (2008), “An Empirical Assessment of Spectator-Based Brand Equity”, Journal of Sport Management, 22(3), 322-337.

Tabachnick B.G., Fidell L.S (2001), Using Multivariate Statistics (6.Ed.), [Elektronik Sürünüm]. New Jersey: Pearson.

Villarejo Ramos Á.F, F.A. Martín Velicia (2007), "A Proposed model for Measuring the Brand Equity in Sports Organizations”, ESIC-Market, 127, 331-374.

Williams A.S. (2010). Examining the Role of Brand Associations in Multipurpose Fitness Facilities: The Relationship Between Service Quality, Exercise Commitment, Brand Associations, and Brand Loyalty. Doctoral Dissertation, Indiana University.

Yoo B, N. Donthu, S. Lee (2000), “An Examination of Selected Marketing Mix Elements and Brand Equity", Journal of the Academy of Marketing Science, 28(2), 195211.

Yildız Y. (2016), “A Research on Soccer Teams' Brand Associations”, The Sport Journal, 56 (19).

Yıldız Y, C. Ay, S. Özbey (2012), "Futbol Takımlarında Tüketici Temelli Marka Değeri: Bir Model Önerisi”. Ege Akademik Bakış, 12,1-10. 